\title{
DEFECTS IN AFFORDABLE HOUSING PROJECTS IN KLANG VALLEY, MALAYSIA
}

\author{
Hamzah Abdul-Rahman ${ }^{1}$, Chen Wang ${ }^{2}$, Lincoln C. Wood ${ }^{3}$, You Min Khoo ${ }^{4}$ \\ Corresponding Author: Dr. Chen Wang \\ Corresponding Email: derekisleon@gmail.com \\ Tel: +603-79673203 \\ Fax: +603-7967 5713
}

\section{ABSTRACT}

Several affordable housing programs have been introduced by the government to achieve the objectives of several Malaysia Plans; however, the success of the housing programs has been reduced due to readily reported quality problems and defects. This research aims to identify the types of defects in affordable housing and determine what is causing the defects, so that solutions may be devised to raise the quality of housing stock in Malaysia. A questionnaire survey was distributed to 310 residents of affordable housing, located in four different regions in Klang Valley, Malaysia. The most commonly occurring defects in affordable housing are leaking pipes, total failure of water supply systems, cracking in concrete walls, faulty door knobs, and dampness to concrete walls. This suggests that improvements in workmanship, the use of superior materials, and changes to more customer-oriented supervision and monitoring may reduce the incidence of defects. Local conditions, such as heavy rainfall, may influence dampness, and may reduce the generalizability of findings to other areas with different weather patterns. The findings have been reported to the Construction Industry Development Board of Malaysia to improve the quality of affordable housing.

Keywords: Defects dissection, Low cost housing, Affordable housing, Building defects, Building quality

\footnotetext{
1 , Professor, Ph.D, Faculty of Built Environment, University of Malaya, 50603 Kuala Lumpur, Malaysia Tel:+603-7967 3203 Fax:+603-796 75713

${ }^{2}$ Senior Lecturer, Ph.D, Faculty of Built Environment, University of Malaya, E: derekisleon@gmail.com

${ }^{3}$ Senior Lecturer, School of Information Systems, Curtin University, Australia, E: cipmgroup@gmail.com

${ }^{4}$ Research Fellow, Ph.D, Faculty of Built Environment, University of Malaya, E: tanying10@yahoo.com
} 


\section{INTRODUCTION}

The low cost housing has always been criticised for poor quality and defective outcomes (Elias, 2003; Abdellatif and Othman, 2006). Rinker (2008), in his report on affordable housing issues, pointed out that public housing projects have deteriorated badly due to a combination of hasty construction, poor design, and insufficient maintenance. Frequently, customers and end-users of lowincome building projects complain that their accommodation does not meet their expectations and are not designed to suit their requirements (Abdellatif and Othman, 2006). Construction defects could be due to substandard construction strategies, faulty workmanship inside and outside the house, bad building materials, improper soil analysis, and preparation or poor drainage systems (Auchterlounie, 2009). Construction defects could also be the result of improper design or installation deficiencies. One of the most common problems faced by house purchasers in Malaysia is the sub-standard construction of houses (Sufian and Abdul-Rahman, 2008). Despite the Malaysian government's commitment in providing adequate, affordable and quality houses for all income level groups with emphasis on the development of low cost housing, there continues to be challenges in developing the housing sector (Ariffian et al., 2010). The low cost housing provided did not meet the demands of the low-income groups. Many of these problems are related to the poor quality of workmanship and inadequate supervision during construction (Trevor, 2009). Low- and middleincome housing has also been shown to suffer from a variety of defects in Malaysia. There has also been a widely-reported case where the residents from the Rista Villa apartments, in Taman Putra Perdana, complained that there were huge cracks appearing at the bottom of the apartment and the situation become worse with the completion of the South Klang Valley Expressway (SKVE). 
Substandard housing and defective construction may be caused by several factors. Ong (1997) reported that developers show less incentive to furnish quality housing, particularly in terms of workmanship, if their real estate assets are sold before completion. Accordingly, their reduced efforts lead to more defective construction and subject house purchasers to a greater degree of housing defects. Holmstrom (1979), Rogerson (1985), and Shavell (1979) have asserted that "Build Then Sale" discourages developer efforts. House purchasers must also rely on architects to supervise the quality of their house construction. As the architects are frequently employed by the developers, home buyer scepticism of their credibility is unsurprising (Sufian and Abdul-Rahman, 2008). Therefore, house purchasers often face difficulties in evaluating the physical construction quality (Forsythe, 2008).

Klang Valley is a region in Peninsula Malaysia which comprises the capital city of Malaysia, Kuala Lumpur, and surrounding suburbs as shown in Figure 1. Also known as the Kuala Lumpur conurbation, it is the fastest growing region in Malaysia (Tan, 2011) and has a population of around 7.2 million in an area of about $3,200 \mathrm{Km}^{2}$. Klang Valley is a low-lying area (Zain-Ahmed et al., 1998) that begins in the north-east of the Kuala Lumpur and is an area with many major towns, including Petaling Jaya, Subang, Shah Alam, and Klang. As reported by the Ministry of Finance's Valuation and Property Service Department (2009), more than $45 \%$ of houses recently constructed in Malaysia were located in the Klang Valley. Due to the importance of affordable housing in this rapidly growing region, the of this study is to identify the types and causes of frequently occurring construction defects within the affordable housing in the Klang Valley, Malaysia.

\section{AFFORDABLE HOUSING IN KLANG VALLEY, MALAYSIA}


Affordable housing was defined as appropriate housing units of which the construction is in accordance with standards comply with code of practice specially created for low cost houses as stated in CIS 1: 1998 and CIS 2:1998 which were publish by CIDB. Defined in the context of Malaysia, a low-cost house is a living unit with a selling price ranging from RM 25,000 to RM 42,000 based on the value of land developed. Affordable housing could be a terrace, detached house or flat with minimum design specifications of a built up area between $600-750$ sq feet, with a living room, a dining area, a kitchen, a bathroom, three bedrooms, a washing and a drying area. Those eligible to own a unit under the low cost housing are those with a monthly household income ranging from RM750-RM1500. In some cases, houses may be rented out at a low monthly rate. To improve the quality of life, social facilities like religious centres, schools, open spaces, recreational areas, community halls, and libraries are also provided (Government of Malaysia, 2010).

Early in 2010, residential property transactions of all types increased in the Klang Valley. The Managing Director of CB Richard Ellis Malaysia, asserted that market sentiment in 2010 was more optimistic than in 2009, but cautious optimism was advised. Following a good fourth quarter of 2009 , the property market was expecting the positive sentiment to continue in 2010 , witnessing a fresh enthusiasm and high levels of activity. This may be linked to overall bullish economic sentiment for 2010 , as regional investors became increasingly interested in the Malaysian property market (CBRE, 2010).

There are a total 100,105 units of existing low cost housing in Wilayah Persekutua, Kuala Lumpur, consisting low-cost houses and flats. However, Selangor, with a total of 279,018 affordable housing units, is the state with the highest number of affordable housing units, followed by Johor, with a total of 168,949 units. This means that there are a total of 379,123 units, about $37 \%$ of the affordable housing in Klang Valley; over $70 \%$ of housing stock in Klang Valley consists of affordable units, 
such as terraced houses, low-cost houses, and low-cost flats. Low cost housing is the second large type which makes up $22 \%$ from all type of existing houses in Klang Valley. Less than $20 \%$ of existing housing units are condos or apartments. The completed affordable housing in Kuala Lumpur is 2,866 units. Pulau Pinang is the state with the highest proportion of affordable housing (18.2\%); Kuala Lumpur has the second highest proportion (18.2\%), followed by Selangor (10.8\%).

\section{DEFECTS IN HOUSING}

Several categories of defects in housing have been previously identified. According to Garrand (2001), defects in buildings and housing can be classified into a number of categories including defects in foundation and ground floor structures, external walls, roofs, internal walls and floors, above ground services, below ground drainage, and external works (Table 1).

Many researchers and commentators have discussed the various causes of defective work in the construction industry. Based on their discussions and analyses, the causes of defective work can be classified into a smaller number of categories (Table 2).

\section{RESEARCH PROCEDURES AND ANALYSIS METHODS}

A questionnaire survey was utilized in this research. There are two fundamental types of questionnaire design: open-ended and close-ended (Lodico et al., 2010; Peterson, 1944). In this research, close-ended questions were used to seek the most frequent types of defects that occurred in affordable housing in Klang Valley, Malaysia. In addition, there are two types of self-administration 
procedures for questionnaires: a) self-administration in the presence of the researcher, and b) selfadministered questionnaires without the presence of the researcher. Self-administered questionnaires in the presence of the researcher were used during this research project as it allowed queries or uncertainties to be addressed immediately and it typically ensures a high response rate. The disadvantage of self-administered questionnaires, without the presence of researcher, is that respondents may misunderstand, or have difficulties understanding the questions, which leads to inaccurate answers or no answer. The researchers felt that this was a particular risk, particularly for those respondents that live in the affordable housing areas and do not have any formal education, as many of them are senior citizens.

There were 310 participants involved in the research, who live in affordable housing residences in the Klang Valley. Since this questionnaire survey was self-administrated in the presence of the researcher, all these 310 respondents completed their forms assisted by the researcher. Questionnaires were distributed in the following areas in Klang Valley: PPR Kerinchi, Taman Bukit Angkasa, Taman Desa Ria, PPR Kampung Baru Air Panas, and Taman Putra Damai in the year 2011 after a pilot study. The sample size is similar to Omar's (2008) study, the aim of which was to interpret the natural communal living environment in Malaysian affordable housing. The selected affordable housing areas were suggested by the Ministry of Housing and Local Government, thus the details have a great extent of reliability. Data analysis was conducted using the following tests including: a) Cronbach's Alpha, b) Frequency Analysis, c) One Sample T-Test, d) Scale Index Analysis, e) Scale Index Analysis, f) Correlation, and g) Partial Correlation.

The numbers of respondents from each affordable housing area (Table 3) and the overall profile of the respondents (Table 4) were also recorded. A higher proportion of respondents were owners of their housing unit. Most respondent were female. Most of the respondents are more than 31 year old; 
the highest numbers of respondents are more than 50 years old. This may be due to the distribution of questionnaires being conducted during the weekday during working hours; many middle-aged respondents would have been at work and unable to respond.

A significant proportion of respondents had lived in their housing units for 4-6 years. This is likely because residents from Taman Desa Ria and PPR Kampung Baru Air Panas, which are two of the affordable housing areas where the questionnaire was distributed, only started to move in only around six years before the research. 31.6\% had residency lengths greater than 10 years; 29\% had habitation periods of 1-3 years; only $2.9 \%$ had a length of residency of $7-10$ years. $60 \%$ had, at the highest, secondary education; $27.4 \%$ of respondents had the highest level of education at the primary school level; only $9.4 \%$ of respondents had tertiary education.

Approximately 44\% of respondents had a monthly family income between RM1001-1500. While 27 $(8.9 \%)$ of them have monthly family income level less than RM500; 107 (35.3\%) of respondents have monthly family income level between RM500 - RM 1000 and lastly 36 (11.9\%) numbers of respondents have monthly family income level more than RM1500. However, around $2.3 \%$ refused to provide their monthly family income level, possibly to protect their privacy.

\section{ANALYSIS INTERPRETATION AND RESULTS}

\section{Reliability Test}

The overall Cronbach's Alpha coefficient for total of 25 variables is 0.855 (Table 5) which is also an acceptable reliability Cronbach's coefficient (Nunnally, 1978). This is a method to test the internal 
consistent score of one variable with composite scores from the remaining variables. According to De Vaus (2004), the variables with Corrected Item-Total Correlation value lower than 0.30 should be removed; as all of the Corrected Item-Total Correlation values exceeded 0.30, no variables were removed. Furthermore, the last column in Table 5 displayed the Cronbach's Alpha if item deleted with the purpose to determine variable to contribute to the overall alpha value. The removal of any one variable only causes minor differences to the overall Cronbach's alpha and so all variables were retained.

\section{Most Common Defects in Affordable Housing}

Respondents were required to determine how frequently the listed defects occurred in their units according to the scales provided, to identify the type of defect that most frequently occur in low cost housing. The frequency for each type of defect, including their corresponding percentage, mean, standard deviation, and rank are tabulated in Table 6. A total of 25 defects are rank from 1 to 25 .

The most frequently occurring defect was leaking pipes (mean value at 2.59); around 16.1\% of respondents acknowledged that this defect was very frequently a problem in their housing area. This includes both the piping internal to the unit in addition to the external piping system. The second most common defect reported by respondents was the total failure of water supply system (mean value of 2.48 , slightly lower than for leaking pipes); $9.4 \%$ of participants claimed that the water supply to their housing unit failed very frequently.

Cracks in the external walls had the third highest mean and $24.2 \%$ of residents reported that this defect occurred very frequently. Moreover, this defect also has the highest standard deviation figure $(\mathrm{SD}=1.21)$ of all the defects, representing significant volatility of opinion amongst respondents. 
Other significant defects included faulty door knobs (mean of 2.25) and dampness to concrete wall (mean of 1.94). These four defects have similar mean values, allowing us to claim that these are the most frequently observed defects in the construction of affordable housing in Klang Valley.

\section{One Sample T-Test}

One sample t-tests were utilised to identify whether the various defects occurred in affordable housing in Klang Valley. Since for "never" occur scale of defect is 1 and "rarely" occur scale of defect is 2 , the test value is set at 1.5 for occurrence of defects in low cost housing. The test value is set at 1.5 instead of 4 which the very frequent occurrence defect because it is not logic for a house unit to has all defects listed in questionnaire occur frequently as it is unsafe for a living space. Hence, this test is to examine defect that exist in low cost housing and among them identify the most frequent occurrence defects. The hypotheses are shown as follows:

$\mathrm{H}_{0}: \mu=1$ (This hypotheses represent that defect has never occur in low cost housing) $\mathrm{H}_{\mathrm{A}}: \mu \geq 1$ (This hypotheses represent that defect has occur in low cost housing)

The output of one sample t-test is displayed in Table 7. The second column of the table represent the t-statistical value obtains, and the third column is the p-value of the test. To interpret the results of one sample $t$-test, each of the variables are compared with two-tailed critical $t$ value of \pm 1.965 , obtained representing a significance of 0.05 at the $95 \%$ confidence level. Most of the defects were statistically significant (Table 7), except for distortion and cracking of ground floor $(\mathrm{t}=-0.519)$, poor ventilation system $(t=-1.33)$, uneven floor finishes $(t=0.817)$, uneven wall plaster $(t=0.314)$, broken floor tiles $(t=-0.73)$ and broken wall tile $(t=-1.921)$. The null hypothesis, $\mathrm{H}_{0}, \mu=1$ was rejected for 19 defects which have significant level less than 0.05 . 


\section{Categories for Each Type Defect}

A scale index can be created using the mean value for each type of defect, based on the maximum and minimum mean values from the total of 25 defects. Each defect is classified by frequency of occurrence, using four scales: "never", "rarely", "frequent", or "very frequent". The formula for the scale index is shown in Eq. (1).

Average Scale Deviation, $x=($ maximum mean-minimum mean)/number of scale (1)

Knowing the value of average scale deviation, the degree of frequency for "never", "rarely", "frequent" and "very frequent" are illustrated in Eq. (2), Eq. (3), Eq. (4) and Eq. (5) respectively.

Index scale for "never" = minimum mean $+x=x_{1}+x=x_{2}$

(Degree of frequency for "never" is $x-x_{2}$ )

Index scale for "rarely" $=x_{2}+x=x_{3}$

(Degree of frequency for "rarely" is $>x_{2}-x_{3}$ )

Index scale for "frequent" $=x_{3}+x=x_{4}$

(Degree of frequency for "rarely" is $>x_{3}-x_{4}$ )

Index scale for "very frequent" $=x_{4}+x=x_{5}$

(Degree of frequency for "rarely" is $>x_{4}-x_{5}$ ) 
The defects were rearranged according to their scale and categorized by frequency. The type of defect, with frequency and number; and percentage of defects for each category of frequency of occurrence are depicted in Tables 8 and 9, respectively.

Twelve (48\%) types of defects are almost never observed in Klang Valley, and this categorisation of infrequent occurrence contains the greatest proportion of defects, with mean values ranging from 1.16 to 1.52 . These defects include all those relating to the roof (water staining, mould growth and decay on roof, deterioration of roof covering, and deformation and displacement of the roof) and the below ground drainage and external wall defects. This indicates the roofing and below ground drainage are less problem-prone than other elements of construction in affordable housing in Klang Valley. Eight types of defects (32\%) are considered to be rarely occurring, with mean values ranging from 1.52 to 1.88 . These include internal staining, mould growth as well as fungal decay on external wall, inadequate resistance to the passage of sound, distortion and cracking of partition, uneven floor finishes, broken window knobs, faulty sanitary installation, faulty electrical fitting and leakage of water tank. The number of 'rarely' occurring defects are second only to the number of 'never' occurring defects, and consist primarily of defective problems relating to internal walls and flooring. Cracking in external walls, total failure of water system, faulty doors and knobs, and leakage of pipes are all considered to occur very frequently. Interestingly, only one defect, dampness to concrete wall, is considered to occur frequently.

\section{Correlation between Types of Defects}

The presence of correlations between types of defects may present opportunities for rapid improvements in construction techniques. The correlation matrix between the most common defects 
found in low cost housing is presented in Table 10. Positive coefficients indicate that both defects tend to be present; negative coefficients indicate that where one defect is present the other tends to be absent.

Three defects, the cracking in external walls, dampness of concrete walls, and leaking pipes, are all significantly correlated. There is a strong relationship between cracking in external walls and dampness to concrete wall $(\mathrm{r}=0.575$ and the correlation is significant at the $1 \%$ level). This may occur as water is able to penetrate between the cracks in the wall and cause dampness in concrete wall. There is also a strong correlation between dampness to concrete wall and the leakage of pipes ( $\mathrm{r}$ $=0.535$, significant at the $1 \%$ level). This is probably due to water from the leaking pipes collecting and consequently dampening the concrete walls. Leaking pipes are moderately correlated with cracking in external walls $(\mathrm{r}=0.412$, significant at the $1 \%$ level). These three defects are correlated and may be jointly caused as the piping systems may be laid in concrete walls; when a concrete wall cracks, or there is movement in the wall, the pipe laid in the wall may break, causing the release of water. The, total failure of water supply systems was weakly correlated with cracking in external walls, dampness to concrete walls, faulty door knobs.

\section{Partial Correlation Matrix of Variables Controlling for Total Failure}

Correlation tests only identify correlation between two variables and so partial correlation was used to further analyse relationships between greater numbers of variables. Partial correlation analysis is utilized to determine the relationship between three defects, by controlling a particular defect; it identifies the unique variance between two defects by eliminating the variance from a third defects.

\section{Partial Correlation Matrix of the Variables, controlling for cracking in external wall}


By removing the variation associated with cracking in external walls, as illustrated in Table 11, the results of correlation between two defects are compared with the correlation output in Table 10. The correlation coefficients between dampness to concrete wall and leaking pipes decreases to $\mathrm{r}=0.401$, while remaining significant at the $1 \%$ level. This indicates that the correlation between these other defects is affected by the cracking of external walls. Careful construction of the external walls should therefore prevent leaking pipes and dampness in the concrete wall from occurring. Correlations between other defects are not affected greatly by controlling for the cracking in external wall defect.

\section{Partial Correlation Matrix of the Variables, controlling for total failure of water supply system}

Table 12 presents the partial correlation of the variables when controlling for the total failure of water supply systems. The correlation between dampness to concrete walls and cracking in external walls $(r=0.563)$, and the correlation between leaking pipes and dampness to concrete wall $(r=$ 0.524 ), both remain high and significant at the $1 \%$ level. This indicates that relationships between the pairs of defects remain strong, irrespective of the failure of water supply systems.

\section{Partial Correlation Matrix of the Variables, controlling for dampness to concrete wall}

Generally, all the coefficient value for all variables has decreased when the dampness to concrete walls is controlled for (Table 13); this defect is significantly associated with other defects. Therefore, many other defects can be prevented by properly constructing damp-proofed concrete walls. The correlation coefficient between cracking in external walls and leaking pipes $(r=0.151$, significant at the $1 \%$ level) is less strong than it is if the dampness to concrete walls is not controlled for $(\mathrm{r}=$ 
0.412 ); the coefficient decrease by 0.261 . In other words, the correlation between them is influenced by dampness to concrete wall.

\section{Partial Correlation Matrix of the Variables, controlling for faulty door knobs}

It can be said that the correlations between defects are not markedly affected by controlling for faulty door knobs (Table 14) indicates that some coefficients increase while others decrease). This means that defective door knobs have little impact on other defects.

\section{Partial Correlation Matrix of Variables, controlling for leakage of pipe}

There is a clear correlation between cracking in external walls and dampness to concrete walls (Table 15), where the relationship decreases from a strong $(r=0.575)$ to moderate $(r=0.460)$ relationship when the leaking pipes are controlled for, while still significant at the $1 \%$ level. This is clearly seen in the correlation between cracking in external and dampness to concrete wall where the relationship between from decrease from strong to moderate with the p-value at less than $1 \%$ significant level relative to output of correlation. This result may occur as without leaking pipes inside the concrete walls, there will be no water flow through cracks in external walls, and therefore the dampness to the concrete will decrease. In other words, the defects of cracking in external walls and dampness to concrete walls will likely be strongly reduced through careful and proper installation of piping systems.

\section{DISCUSSION ON FINDINGS}


With the increase in demand for housing, mainly due to high urbanization rates, there is an emphasis on the development of affordable housing solutions by the Malaysian Federal Government. Apart from providing adequate housing for low-income groups, the housing policy also emphasizes the significance of comprehensive settlement planning to achieve safe and decent living conditions. This is in line with the Eighth, Ninth, and Tenth Malaysian Plans, which have the objective of increasing the quality of affordable new and existing homes. Our research found that most participants identified defects that were similar to those identified through the literature review. Results from the questionnaire shows the most common defect occurring in affordable housing is leaking pipes. Approximate $17 \%$ of low cost housing residents admitted that pipe leakage always happen in their housing unit and about $40 \%$ report that leakage of piping is a frequent problem for them. Another significant problem is the total failure of water supply system. This defect has created many inconveniences to residents; without water supply, many core household activities are simply not possible. Cracking in walls is a commonly occurring defect that occurs in almost all housing units, whether they are low-, medium-, or high-cost housing. It is undeniable that cracking in external walls is another common defect in affordable housing. While cracks are the third most frequently occurring defect in affordable housing, $75 \%$ revealed that this defect happens very frequently in their housing unit; this indicates that cracking of walls is a very widely spread problem, while the leaking pipes and water supply problems may be isolated to a smaller number of construction projects. Another two frequently occurring defects are dampness to concrete walls and faulty door knobs. Although these five defects are considered as the most frequent defects in low cost housing, dampness to concrete wall is found to be a defect that is described as a "frequent" occurrence, while the others are attributed as "very frequent" occurrences. Thus, from the findings of questionnaire survey, it was proven that there is quality problem is faced by residents in affordable housing. 
There are also significant correlations between the top five frequent defects. Moderate or strong correlations exist between the defects of cracks in external walls, leaking pipes, and dampness to concrete walls. This indicates that when one of the defects exists, it is likely that the others will occur simultaneously. This indicates that one of the defects is causing the other two, or that there is a fourth, unseen, influence that is possibly causing all three defects. It seems likely, however, that properly constructed external walls may prevent cracking of concrete walls and this may prevent the other defects from occurring, particularly leaking pipes.

The respondents are drawn from five different areas of affordable housing located in Klang Valley, two of which were constructed under the PPR affordable housing project. Some of the residences were completed about ten years ago, while some were completed less than five years ago. Residents from various affordable housing programs, covering different periods of habitation, were chosen as respondents because the research aims to collect information adequate to provide an overview of the problems with construction in Klang Valley, Malaysia.

Several crucial factors have been identified that may improve the quality of such affordable housing. The first factor is to increase the ceiling, or selling price, of low cost housing, or to secure larger government subsidies. This can be considered as the main factor as other factors are also related to this factor. Due to construction cost pressures driven largely by a low ceiling price, many constructors may have opted for materials of low quality and employed unskilled labour to undertake work, which reduces their costs. Another cost-related issue is the land value in Klang Valley, which is higher than many other Malaysian states, as this causes otherwise identical low-cost developments to be higher-cost than in other states. Therefore, an increase of the ceiling price, improved government subsidies, or the presence of a greater weighting of subsidies for areas, like Klang Valley, with higher land costs, may improve the overall quality of affordable housing. Other efforts 
may be directed towards securing high quality materials, or ensuring a steady supply of skilled labourers, to support the construction industry.

Site supervision and monitoring is required by both the client team and the main construction company. It is important for the client team to carry out site supervision and inspection trips from time-to-time; construction workers tend to properly execute work when there are client representatives to supervise their work, or when a client representative may suddenly appear. The same goes to the main contractor: as much of the construction work is subcontracted, it is crucial for the main contractor to monitor the work instead of managing the coordination of work among all subcontractors.

As most of the defects in affordable housing can be due to poor workmanship, employing more skilled workers may also improve the overall quality of construction. Many training sessions for laborers are provided by CIDB, with the aim of providing more skilled workers to the Malaysian construction industry. Thus, contractors may also send their laborers to attend these training sessions, improving the workers skills, and creating a higher-quality final product.

\section{Leakage of Pipes}

From the questionnaire findings, leaking pipes were identified as the most frequent defect in affordable housing in Klang Valley. This defect occurs in the both external and walls and wet areas, such as the kitchen and toilet. This is supported by Georgious et al. (1999) conclusions, reached in a study comparing defects found in constructions by owners and registered builders, which found that both categories led to plumbing defects as major defects. However, our finding is similar to the conclusions reached by Chew (2005), which only focused on defects in the wet areas of buildings. 
Chew identified water leakage through pipe penetration to be the fourth most frequently occurring defect. The leakage of piping was identified as the most commonly occurring defect mainly due as affordable housing have piping systems above ground, rather than being underground; such construction simplifies later maintenance work, but exposes pipes to increased risk of damage over time. Therefore, pipe leakage occurs easily and is the most frequently occurring defect in affordable housing.

\section{Total Failure of Water Supply System}

The total failure of water supply systems was identified as being the second most common defect in affordable housing. This is supported by Kazaz and Birgonul (2005), who determined that the water supply system is the most unsatisfactory product or service in high-rise and medium-density housing units. Most of the water supply systems in affordable housing in the Klang Valley operate with a pumping system, where the pump machine distributes water to each of the housing units in the block. However, there is only one pump for each block; when the pumping system fails, the water supply for the whole block will cut off as there is no backup system to distribute water. This means that failures will be clustered, and reported by several residents in the block.

\section{Cracking in External Wall}

Generally, there are two main types of cracking in external walls. One type is caused by structural movements which usually cause cracks that mirror the horizontal and vertical planes of the mortar joints, often varying in width and running at oblique angles. Another type is cracking is caused by temperature changes. These are usually of uniform width and cut straight through materials at the weakest, or least restrained, part of the wall (Garrand, 2001). Our findings indicate that cracking in 
external walls was found to be the third most common defect Klang Valley's affordable housing. This is aligned with other research, such as Olubodun and Mole (1999) suggesting that expansion cracks have the highest mean for design factors in building, and a range of previous studies that identified cracking as a commonly occurring category of defects (Georgious et al. 1999; Trotman, 1994; Georgious, 2010).

\section{Faulty Door Knobs}

The fourth most frequently occurring defect in affordable housing that we identified is faulty door knobs. This is most likely due to substandard materials being utilized and poor workmanship. Workmanship is usually identified as the first or second major source of defects (Georgious, 2010). The present research differs from past research as the faulty door knob may be caused by poor workmanship or substandard materials.

\section{Dampness to Concrete Wall}

Traditionally, walls are protected from rainfall by overhanging eaves fitted with gutters and downpipes. Nevertheless, rain may still be blown onto the surface of the wall (Richardson, 2001) and can cause dampness to concrete wall. This is particularly problematic in Malaysia, as it is considered to have a heavy rainfall in comparison to many other countries. In this research, dampness to concrete walls was identified as one of the top five commonly occurring defects in affordable housing. This conclusion is supported by previous research (Trotman, 1994; Georgious et al., 1999); however, our ranking for the occurrence may be different and this is likely to be due to the fact that other countries have different rainfall patterns, and so dampness may occur less frequently than in Malaysia. 


\section{CONCLUSION AND RECOMMENDATIONS}

The research is focused on affordable housing in the Klang Valley, Malaysia, where more than $70 \%$ of housing stock consists of units in affordable market segments. These include terraced houses, lowcost houses, and low-cost flats. They key findings are that the most commonly occurring defects in affordable housing are leaking pipes, total failure of water supply systems, cracking in concrete walls, dampness to concrete walls, and faulty door knobs. The first three of these defects are strongly correlated, suggesting a common underlying cause that may be readily identified and rectified. This may be the cracking of external walls, which affects the water pipes, causing leaks, and allowing this, plus rainfall, to cause increased dampness in the walls. We infer that the common causes of these defects may be poor workmanship, inferior materials, and poor supervision and monitoring routines. Increasing involvement of clients-oriented monitoring and supervision on the worksite may improve subcontractor performance, influencing the quality of the final job. This may be particularly pertinent to the construction of the external walls, given the relationship between defective construction of walls and the presence of other construction defects. These findings have been reported to the Construction Industry Development Board of Malaysia to improve the quality of affordable housing.

A number of areas which would be worth investigating further, as they may prove to be beneficial to the industry, have been identified. First, the study could be broadened to understand the defects in affordable housing over all of Malaysia, or the entire South East Asian region, particularly emphasising how housing quality can also be improved in rural areas. Second, defects could be compared in those low-cost projects constructed by the public and private sectors. Public sector 
bodies would be expected to be more accountable and should have correspondingly fewer defects than private sector firms. This may be informed by a more detailed investigation into the defects associated with the People Housing Program (PHP). Third, as it is not possible to determine causes of defects with our current research design, follow-up research focusing on the industry and construction techniques may uncover the causes of the defects, and how they can be prevented. Fourth, as construction methods and political expediency influence the construction of affordable housing over time, the differences in quality in recent affordable housing units, compared with those constructed before 2000, would be interesting and may indicate problems in societal and political influences that lead to greater levels of defects. Fifth, broader research can be conducted to understand how society can overcome challenges to providing sustainable urban development of affordable housing solutions in Malaysia.

\title{
REFERENCE
}

\begin{abstract}
Abdellatif, M.A. and Othman, A.A.E. (2006). "Improving the sustainability of low-income housing projects: The case of residential buildings in Musaffah commercial city, Abu Dhabi", Emirates Journal for Engineering Research, 11(2), 47-58.
\end{abstract}

Ariffian, B.A., Abu Zarin, H., and Jumadi, N. (2010). "The relationship between demographic factors and housing affordability", Malaysian Journal of Real Estate, 5(1), 49-58.

Auchterlounie, T. (2009). "Recurring quality issue in the UK private house building industry", Structural Survey, 27(3), 241-251. 
Chan, A.P.C., Wong, F.K.W., and Lam, P.T.L. (2005). "Assessing quality relationship in public housing", International Journal of Quality \& Reliability Management, 23(8), 909-927.

Chew, M.Y.L. (2005). "Defects analysis in wet areas of buildings", Construction and Building Materials, 19, 165-173.

Cohen, L., Manion, L., and Morrison, K. (2007). Research Methods in Education. Taylor \& Francis Group, London.

De Vaus, D.A. (2004). Surveys in Social Research. Routledge, Australia.

Elias, I. (2003). "Achieving Quality in Housing Construction through Standradisation", $2^{\text {nd }}$ Asian Forum Conference Tokyo. 20-30 January, pp.1-3.

Forsythe, P. (2008). "Modelling Customer Perceived Service Quality in Housing Construction", Engineering, Construction and Architectural Management, 15(5), 485-496.

Garrand, C. (2001). HAPM Guide to Defect Avoidance. Spon Press, London.

Georgiou, J, Love, P.E.D., and Smith, J. (1999). "A comparison of defects in houses constructed by owners and registered builders in the Australia state of Victoria", Structural Survey, 17(3), 160-169.

Georgious, J. (2010). "Verification of a building defect classification system for housing", Structural Survey, 28(5), 370-383. 
Government of Malaysia. (2010). Tenth Malaysia Plan, 2011-2015. The Government Press, Kuala Lumpur.

Hall, M. and Tomkins, C. (2001). "A cost of quality analysis of a building project: toward a complete methodology for design and build", Construction Management and Economics, 19, 727-740.

Hammarlund, Y. and Josephson, P.E. (1991). "Source of quality failure in building. Proceeding of the European symposium on management", Quality and Economic in Housing and Other Building Sector, Lisbon, Portugal, 30 September -4 October, pp. 671-679.

Holmstrom, B. (1979). "Moral hazard and observability", Bell Journal of Economic, 10(1), 74-91.

Ilozor, B.D., Okoroh, M.I., Egbu, C.E., and Archicentre. (2004). "Understanding residential house defects in Australia from the state of Victoria", Building and Environment, 39, 327-337.

Karim, K., Marosszeky, M., and Davis, S. (2006). "Managing Subcontractor Supply Chain for Quality in Construction Engineering", Construction and Architectural Management, 13(1), 27 - 42.

Kazaz, A. and Birgonul, M.T. (2005). "The evidence of poor quality in high rise and medium rise housing units: A case study of mass housing projects in turkey", Building and Environment, 40, 1548-1556.

Lodico, M.G., Spaulding, D.T., and Voegtle, K.H. (2010). Methods in Education Research: From Theory to Practice, $\left(2^{\text {nd }}\right.$ e.d). Jossey-Bass, San Francisco. 
Lourenco, P.B., Luso, E., \& Almeida, M.G. (2006). "Defects and moisture problems in buildings from historical city centres: A case study in Portugal", Building and Environment, 41, 223-234.

Low, S.P. and Wee, D. (2001). "Improving maintenance and reducing building defects through ISO 9000", Journal of Quality in Maintenance Engineering, 7(1), 6-24.

Ministry of Finance's Valuation and Property Service Department. (2009). Property Market Report. The Government Press, Kuala Lumpur.

Ministry of Housing and Local Government (MHLG). (2012a). Public Low Cost Housing Program. Retrieved on 2010, $3^{\text {rd }}$ November, from http://ehome.kpkt.gov.my/ehome/profil/pakr.cfm

Ministry of Housing and Local Government (MHLG). (2012b). People Housing Program (PHP). Retrieved on $2010,10^{\text {th }}$ November, from http://ehome.kpkt.gov.my/ehome/profil/pprdasar.cfm

Ministry of Housing and Local Government (MHLG). (2012c). People Housing Program for Ownership. $\quad$ Retrieved $\quad 2010, \quad 10^{\text {th }} \quad$ November, $\quad$ from http://ehome.kpkt.gov.my/ehome/profil/pprdimiliki.cfm

Ministry of Housing and Local Government (MHLG). (2012d). People Housing Program for Rental. Retrieved on $201,10^{\text {th }}$ November, from http://ehome.kpkt.gov.my/ehome/profil/pprdisewa.cfm

Ministry of Housing and Local Government (MHLG). (2012e). Integrated People Housing Program for Rental. Retrieved on 2010, $10^{\text {th }}$ November, from http://ehome.kpkt.gov.my/ehome/profil/pprbersepadu.cfm 
Nunnally, J. (1978). Psychometric Theory. McGraw-Hill, New York.

Olubodun, F. and Mole, T. (1999). "Evaluation of defect influencing factors in public housing in the UK", Structural Survey, 17(3), 170-178.

Olubodun, F. (2000). "A factor approach to the analysis of components' defects in housing stock", Structural Survey, 18(1), 46-57.

Omar, D. (2008). "Communal living environment in low cost housing development in Malaysia", Asian Social Science, 4(10), 98-105.

Ong, S.E. (1997). "Building defects, warranties and project financing from pre-completion marketing", Journal of Property Finance, 8(1), 35-51.

Peterson, R.A. (1944). Constructing Effective Questionnaires. Sage, New York.

Rinker, M.E. (2008). Affordable Housing Issues. Shimberg Center for Affirdable Housing. XIX(5): $1-4$.

Rogerson, E. (1985). "The first order approach to the principal-agent problem", Econometrica, 53(3), $1357-1368$.

Shavell, S. (1979). "Risk sharing and incentive in the principal and agent relationship", Bell Journal of Economic, 10(1), 55-73. 
Sufian, A. and Abdul-Rahman, R. (2008). "Quality Housing: Regulation and Administrative Framework in Malaysia", International Journal of Economics and Management, 2(1), 141-156.

Tan, T.T. (2011). "Neighborhood preferences of house buyers: the case of Klang Valley, Malaysia", International Journal of Housing Market and Analysis, 4(1), 58-69.

Trotman, P.M. (1994). "An examination of the bre advisory service database compiled from property inspection", in: Moroni, M. and Sartori, P. (Eds), Proceedings of the International Symposium on Dealing with Defects in Building, Varene, pp. 187 - 196.

Watt, D.S. (1999). Building Pathology: Principles \& Practice. Blackwell Zealand, UK.

Zain-Ahmed, A., Sayigh, A.A.M., Surendran, P.N., and Othman, M.Y. (1998). "The bioclimatic design approach to low-energy building in the Klang Valley, Malaysia", Renewable Energy, 15, 437440.

Trevor, R. (2009). Investigating Defects in Commercial and Industrial Buildings. RICS Books, Coventry.

Figure Caption:

Figure 1: Location of Klang Valley, Malaysia shown in read pane (http://www.malaxi.com/highway_express/images/plus_expressways_map.jpg) 
Table 1: Summary on types of building defects

\begin{tabular}{|c|c|}
\hline Type of defects & Authors \\
\hline $\begin{array}{l}\text { Foundation and floor structure } \\
\text { i. Distortion and cracking of ground floors }\end{array}$ & $\begin{array}{l}\text { Olubodun and Mole (1999), Georgiou et al. (1999), Olubodun (2000), Garrand } \\
\text { (2001), Ilozor } \text { et al. (2004), Lourenco et al. (2006), Georgious (2010). }\end{array}$ \\
\hline $\begin{array}{l}\text { External walls } \\
\text { i. Cracking in external wall }\end{array}$ & $\begin{array}{l}\text { Olubodun and Mole (1999), Georgiou et al. (1999), Olubodun (2000), Garrand } \\
\text { (2001), Ilozor et al. (2004), Kazaz and Birgonul (2005), Lourenco et al. (2006), } \\
\text { Georgious (2010), Thwala (2010) }\end{array}$ \\
\hline ii. Internal staining, mould growth and fungal decay & Garrand (2001), Chew (2005), Lourenco et al. (2006) \\
\hline $\begin{array}{l}\text { Roof } \\
\quad \text { i. Water staining, mould growth and fungal decay }\end{array}$ & Ilozor et al (2004), Garrand (2001), Chew (2005), Thwala (2010) \\
\hline ii. Deterioration of coverings & $\begin{array}{l}\text { Olubodun and Mole (1999), Olubodun (2000), Garrand (2001), Ilozor } \text { et al. } \\
\text { (2004), Lourenco et al. (2006), Thwala (2010) }\end{array}$ \\
\hline iii. Deformation or displacement of roof & $\begin{array}{l}\text { Olubodun and Mole (1999), Olubodun (2000), Garrand (2001), Ilozor } \text { et al. } \\
\text { (2004), Thwala (2010) }\end{array}$ \\
\hline $\begin{array}{l}\text { Internal walls and floors } \\
\begin{array}{l}\text { i. Inadequate resistance to the passage of sound } \\
\text { ii. } \quad \text { Distortion and cracking of partition }\end{array}\end{array}$ & $\begin{array}{l}\text { Watt (1999), Garrand (2001), Olubodun and Mole (1999), Olubodun (2000), } \\
\text { Garrand (2001), Ilozor et al. (2004), Kazaz and Birgonul (2005), Lourenco et al. } \\
\text { (2006), Georgious (2010), Thwala (2010) }\end{array}$ \\
\hline $\begin{array}{l}\text { Above ground service } \\
\text { i. } \quad \text { Failure of water supply system }\end{array}$ & $\begin{array}{l}\text { Garrand (2001), Ilozor et al (2004), Kazaz and Birgonul (2005), Georgious } \\
\text { (2010) }\end{array}$ \\
\hline ii. $\quad$ Poor ventilation system & Watt (1999), Garrand (2001) \\
\hline $\begin{array}{l}\text { Below ground drainage and external works } \\
\text { i. } \quad \text { Surcharge of drains and flooring } \\
\text { ii. } \quad \text { Fracture and displacement of drains }\end{array}$ & $\begin{array}{l}\text { Olubodun and Mole (1999), Olubodun (2000), Garrand (2001), Kazaz and } \\
\text { Birgonul (2005), Georgious (2010) }\end{array}$ \\
\hline $\begin{array}{l}\text { Wall and floor finishes } \\
\text { i. Uneven floor finishes }\end{array}$ & Georgiou et al. (1999), Chew (2005) \\
\hline ii. Uneven wall plaster & Georgiou et al. (1999), Kazaz and Birgonul (2005) \\
\hline iii. $\quad$ Broken floor tiles & Kazaz and Birgonul (2005), Chew (2005), \\
\hline iv. Broken wall tiles & $\begin{array}{l}\text { Olubodun and Mole (1999), Olubodun (2000), Kazaz and Birgonul (2005), Chew } \\
\text { (2005), }\end{array}$ \\
\hline $\begin{array}{l}\text { Damp proof course } \\
\text { i. Dampness to concrete wall }\end{array}$ & Watt (1999), Olubodun (2000), Georgious (2010) \\
\hline ii. $\quad$ Floor dampness & Olubodun and Mole (1999), Olubodun (2000), Georgious (2010) \\
\hline $\begin{array}{l}\text { Door and window fixings } \\
\text { i. } \quad \text { Faulty door knobs }\end{array}$ & Olubodun (2000), Kazaz and Birgonul (2005) \\
\hline ii. $\quad$ Broken window knobs & Olubodun and Mole (1999), Olubodun (2000), Kazaz and Birgonul (2005) \\
\hline $\begin{array}{l}\text { Sanitary installation } \\
\text { i. } \quad \text { Faulty sanitary installation }\end{array}$ & Kazaz and Birgonul (2005) \\
\hline $\begin{array}{l}\text { Electrical installation } \\
\text { i. } \quad \text { Exposed wires }\end{array}$ & Georgiou et al. (1999) \\
\hline ii. Faulty electrical fittings & $\begin{array}{l}\text { Olubodun and Mole (1999), Georgiou et al. (1999), Olubodun (2000), Ilozor et al. } \\
\text { (2004), Kazaz and Birgonul (2005) }\end{array}$ \\
\hline $\begin{array}{l}\text { Piping work } \\
\text { i. } \quad \text { Leakage of pipe }\end{array}$ & Olubodun and Mole (1999), Georgiou et al. (1999), Olubodun (2000) \\
\hline
\end{tabular}


Table 2: Summary on causes of defects

\begin{tabular}{|c|c|}
\hline Causes & Authors \\
\hline Design & $\begin{array}{l}\text { Olubodun and Mole (1999), Olubodun (2000), Low and Wee (2001), Chew } \\
\text { (2005), Karim et al. (2006) }\end{array}$ \\
\hline Aging & Olubodun (2000), Chew (2005), \\
\hline Construction & Olubodun and Mole (1999), Chew (2005) \\
\hline Vandalism & Olubodun (2000) \\
\hline Changing standard & Olubodun and Mole (1999), Olubodun (2000), \\
\hline Client & Chan et al. (2005) \\
\hline User involvement & Hammarlund et al. (1990) \\
\hline Time pressure & Low and Wee (2001), Hammarlund et al. (1990) \\
\hline Cost pressure & Low and Wee (2001) \\
\hline Workers problem & Thwala (2010), Hammarlund et al. (1990), \\
\hline External influence & Olubodun (2000) \\
\hline Tenant's lack of care & Olubodun (2000) \\
\hline Material selection & Low and Wee (2001), Chew (2005), Thwala (2010), Karim et al. (2006) \\
\hline Poor site investigation & Low and Wee (2001), Thwala (2010) \\
\hline Management & Hammarlund et al.(1990), Chan et al. (2005) \\
\hline Workmanship & Chew (2005), Chan et al. (2005), Karim et al. (2006), Hall and Tomkins (2001) \\
\hline Lack of quality & Chan et al. (2005), Thwala (2010) \\
\hline
\end{tabular}

\section{Accepted Manuscript Not Copyedited}


Journal of Performance of Constructed Facilities. Submitted September 13, 2012; accepted October 23, 2012; posted ahead of print October 25, 2012. doi:10.1061/(ASCE)CF.1943-5509.0000413

Table 3: Regional distribution of respondents

\begin{tabular}{|l|c|c|}
\hline \multicolumn{1}{|c|}{ Low Cost Housing Area } & Number of Questionnaire distributed & Percentage (\%) \\
\hline PPR Kerinchi & 72 & 23.2 \\
\hline Taman Bukit Angkasa & 50 & 16.1 \\
\hline Taman Desa Ria & 65 & 21.0 \\
\hline PPR Kampung Baru Air Panas & 60 & 20.3 \\
\hline Taman Putra Damai & 63 & 100.0 \\
\hline Total & 310 & \\
\hline
\end{tabular}

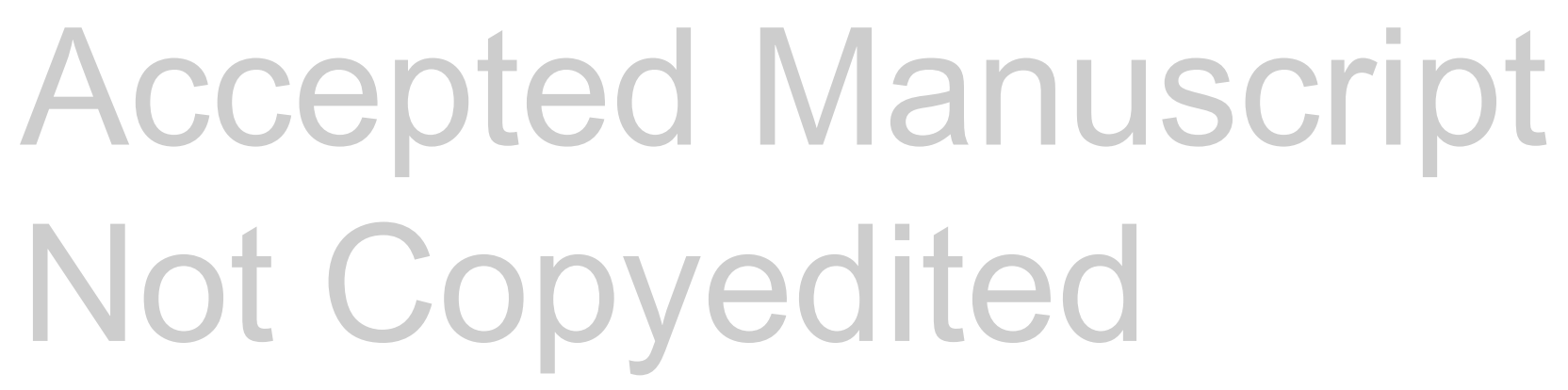


Table 4: Respondents' profiles

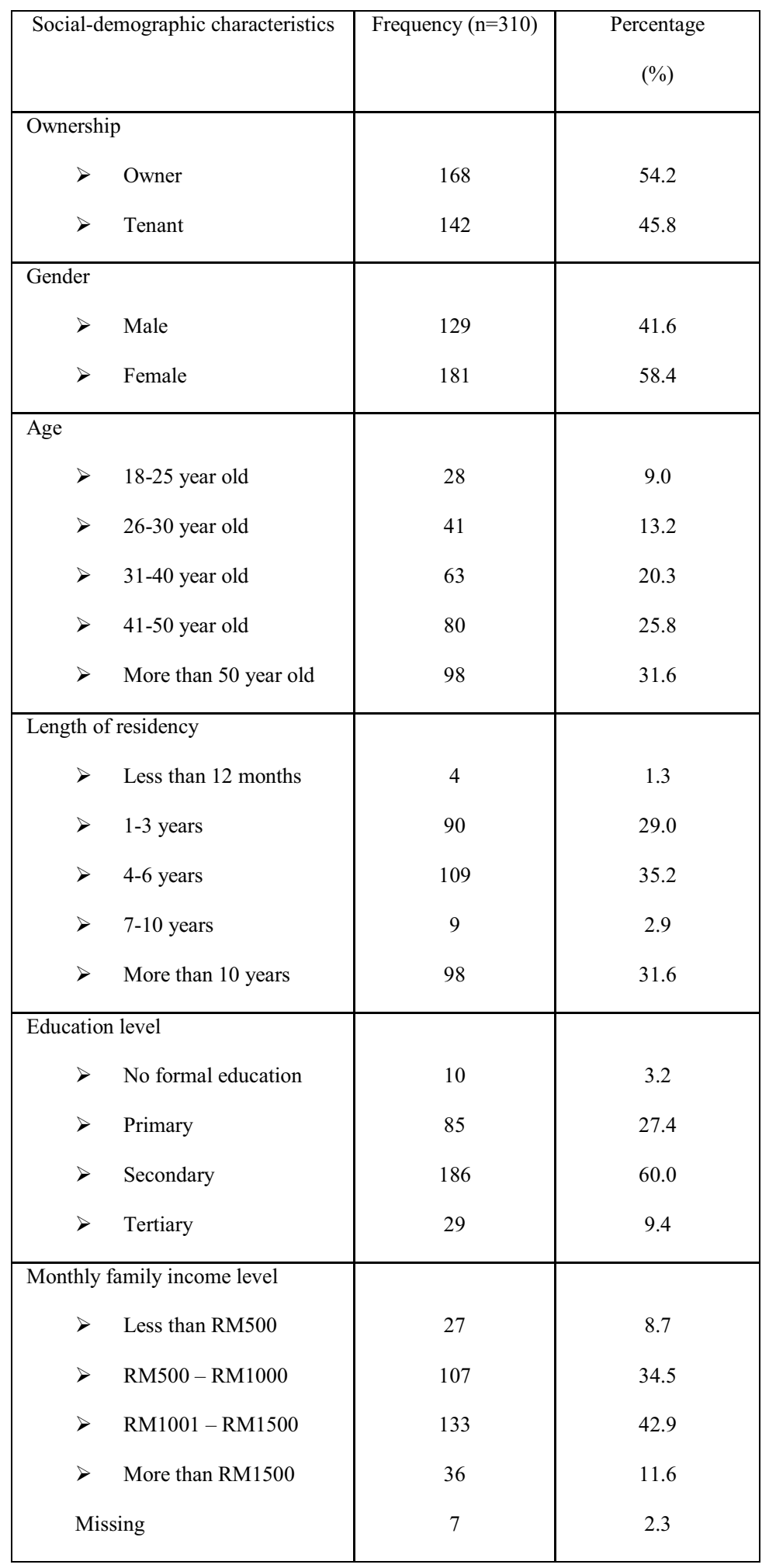

\section{Accepted Manuscript Not Copyedited}


Table 5: Statistical result for reliability analysis

\begin{tabular}{|c|c|c|c|c|}
\hline Type of defects & $\begin{array}{c}\text { Scale Mean if Item } \\
\text { Deleted }\end{array}$ & $\begin{array}{l}\text { Scale Variance if } \\
\text { Item Deleted }\end{array}$ & $\begin{array}{l}\text { Corrected } \\
\text { Item-Total } \\
\text { Correlation }\end{array}$ & $\begin{array}{l}\text { Cronbach's } \\
\text { Alpha if } \\
\text { Item } \\
\text { Deleted }\end{array}$ \\
\hline Distortion and cracking of ground floor & 39.5355 & 67.693 & .460 & .849 \\
\hline Cracking in external wall & 38.7065 & 63.386 & .474 & .849 \\
\hline Internal staining, mould growth and fungal decay on external wall & 39.3774 & 66.372 & .505 & .847 \\
\hline Water staining, mould growth and decay on roof & 39.7645 & 68.459 & 498 & .848 \\
\hline Deterioration of roof covering & 39.8355 & 69.206 & .496 & .849 \\
\hline Deformation and displacement of roof & 39.8032 & 69.667 & .457 & .850 \\
\hline Inadequate resistance to the passage of sound & 39.3419 & 65.061 & .586 & .844 \\
\hline Distortion and cracking of partition & 39.2613 & 65.805 & .604 & .844 \\
\hline Total failure of water supply system & 38.5387 & 66.793 & .426 & .849 \\
\hline Poor ventilation system & 39.5645 & 67.334 & .509 & .847 \\
\hline Surcharge of drains and flooring & 39.8548 & 69.950 & .235 & .855 \\
\hline Fracture and displacement of drains & 39.7097 & 68.466 & .513 & .848 \\
\hline Uneven floor finishes & 39.4839 & 67.254 & .470 & .848 \\
\hline Uneven wall plaster & 39.5032 & 67.681 & .411 & .850 \\
\hline Broken floor tiles & 39.5194 & 67.849 & .364 & .852 \\
\hline Broken wall tiles & 39.5935 & 66.753 & .504 & .847 \\
\hline Dampness to concrete wall & 39.0742 & 65.480 & .476 & .848 \\
\hline Faulty door knobs & 38.7645 & 70.964 & .104 & .861 \\
\hline Broken window knobs & 39.2710 & 67.700 & .473 & .848 \\
\hline Faulty sanitary installation & 39.3935 & 68.078 & .432 & .849 \\
\hline Exposed wires & 39.6290 & 68.590 & .349 & .852 \\
\hline Faulty electrical fitting & 39.4355 & 65.567 & 612 & .843 \\
\hline Leakage of pipe & 38.4226 & 66.077 & .422 & .850 \\
\hline Dampness to floor & 39.6000 & 72.759 & -.010 & .863 \\
\hline Leakage of water tank & 39.4032 & 71.361 & .088 & .861 \\
\hline
\end{tabular}

\section{Accepted Manuscript Not Copyedited}


Table 6: Defects in low cost housing

\begin{tabular}{|c|c|c|c|c|c|c|c|c|c|c|c|}
\hline \multirow{2}{*}{ Type of Defect } & \multicolumn{2}{|c|}{ Never } & \multicolumn{2}{|c|}{ Rarely } & \multicolumn{2}{|c|}{ Frequent } & \multicolumn{2}{|c|}{ Very Frequent } & \multirow{2}{*}{ Mean } & \multirow{2}{*}{$\begin{array}{c}\text { Standard } \\
\text { Deviation }\end{array}$} & \multirow{2}{*}{ Rank } \\
\hline & Frequency & $(\%)$ & Frequency & $(\%)$ & Frequency & $(\%)$ & Frequency & $(\%)$ & & & \\
\hline \multicolumn{12}{|c|}{ Foundation and floor structure } \\
\hline Distortion and cracking of ground floor & 185 & 59.68 & 105 & 33.87 & 16 & 5.16 & 4 & 1.29 & 1.48 & 0.66 & 16 \\
\hline \multicolumn{12}{|c|}{ External wall } \\
\hline Cracking in external wall & 86 & 27.74 & 117 & 37.74 & 32 & 10.32 & 75 & 24.19 & 2.31 & 1.12 & 3 \\
\hline $\begin{array}{l}\text { Internal staining, mould growth and fungal } \\
\text { decay on external wall }\end{array}$ & 159 & 51.29 & 108 & 34.84 & 39 & 12.58 & 4 & 1.29 & 1.64 & 0.75 & 9 \\
\hline \multicolumn{12}{|c|}{ Roof } \\
\hline $\begin{array}{l}\text { Water staining, mould growth and decay on } \\
\text { roof }\end{array}$ & 246 & 79.35 & 50 & 16.13 & 14 & 4.52 & 0 & 0.00 & 1.25 & 0.53 & 22 \\
\hline Deterioration of roof covering & 262 & 84.51 & 40 & 12.90 & 8 & 2.58 & 0 & 0.00 & 1.18 & 0.45 & 24 \\
\hline Deformation and displacement of roof & 246 & 79.35 & 62 & 20.0 & 2 & 0.65 & 0 & 0.00 & 1.21 & 0.43 & 23 \\
\hline \multicolumn{12}{|c|}{ Internal wall and floor } \\
\hline Inadequate resistance to the passage of sound & 155 & 50.00 & 108 & 34.83 & 40 & 12.90 & 7 & 2.26 & 1.67 & 0.78 & 8 \\
\hline Distortion and cracking of partition & 120 & 38.71 & 148 & 47.74 & 40 & 12.90 & 2 & 0.65 & 1.75 & 0.70 & 6 \\
\hline \multicolumn{12}{|c|}{ Above ground service } \\
\hline Total failure of water supply system & 34 & 10.97 & 123 & 39.68 & 124 & 40.0 & 29 & 9.35 & 2.48 & 0.81 & 2 \\
\hline Poor ventilation system & 193 & 62.26 & 96 & 30.97 & 19 & 6.13 & 2 & 0.65 & 1.45 & 0.64 & 17 \\
\hline \multicolumn{12}{|c|}{ Below ground drainage and external wall } \\
\hline Surcharge of drains and flooring & 275 & 88.70 & 31 & 10.00 & 3 & 0.97 & 1 & 0.32 & 1.16 & 0.68 & 25 \\
\hline Fracture and displacement of drains & 223 & 71.94 & 79 & 25.48 & 8 & 2.58 & 0 & 0.00 & 1.30 & 0.51 & 21 \\
\hline \multicolumn{12}{|c|}{ Wall and floor finishes } \\
\hline Uneven floor finishes & 178 & 57.42 & 102 & 32.90 & 27 & 8.71 & 3 & 0.98 & 1.53 & 0.69 & 13 \\
\hline Uneven wall plaster & 186 & 60.00 & 96 & 30.97 & 21 & 6.77 & 7 & 2.26 & 1.51 & 0.72 & 14 \\
\hline Broken floor tiles & 201 & 64.84 & 73 & 23.54 & 27 & 8.71 & 9 & 2.90 & 1.50 & 0.77 & 15 \\
\hline Broken wall tiles & 212 & 68.39 & 72 & 23.23 & 19 & 6.13 & 7 & 2.26 & 1.42 & 0.71 & 18 \\
\hline \multicolumn{12}{|c|}{ Damp proof course } \\
\hline Dampness to concrete wall & 110 & 35.48 & 129 & 41.61 & 50 & 16.13 & 21 & 6.77 & 1.94 & 0.89 & 5 \\
\hline Dampness to floor & 210 & 67.74 & 75 & 24.19 & 21 & 6.77 & 4 & 1.29 & 1.42 & 0.68 & 19 \\
\hline \multicolumn{12}{|c|}{ Door and window fixings } \\
\hline Faulty door knobs & 49 & 15.81 & 162 & 52.26 & 71 & 22.90 & 28 & 9.03 & 2.25 & 0.83 & 4 \\
\hline Broken window knobs & 113 & 36.45 & 163 & 52.58 & 34 & 10.97 & 0 & 0.00 & 1.75 & 0.64 & 7 \\
\hline \multicolumn{12}{|c|}{ Sanitary installation } \\
\hline Faulty sanitary installation & 144 & 46.45 & 140 & 45.16 & 25 & 8.06 & 1 & 0.32 & 1.62 & 0.65 & 10 \\
\hline \multicolumn{12}{|c|}{ Electrical installation } \\
\hline Exposed wires & 222 & 71.61 & 62 & 20.00 & 20 & 6.45 & 6 & 1.94 & 1.39 & 0.70 & 20 \\
\hline Faulty electrical fitting & 166 & 53.55 & 112 & 36.13 & 28 & 9.03 & 4 & 1.29 & 1.58 & 0.71 & 12 \\
\hline \multicolumn{12}{|c|}{ Piping work } \\
\hline Leakage of pipe & 39 & 12.58 & 98 & 31.61 & 123 & 39.68 & 50 & 16.13 & 2.59 & 0.90 & 1 \\
\hline Leakage of water tank & 169 & 54.52 & 98 & 31.61 & 37 & 11.94 & 6 & 1.94 & 1.61 & 0.77 & 11 \\
\hline
\end{tabular}

\section{Accepted Manuscript \\ Not Copyedited}

Copyright 2012 by the American Society of Civil Engineers

J. Perform. Constr. Facil. 
Table 7: One-sample t-test

\begin{tabular}{|c|c|c|c|c|c|c|}
\hline \multirow{3}{*}{ Type of defects } & \multicolumn{6}{|c|}{ Test Value $=1.5 ; \mathrm{df}=309$} \\
\hline & \multirow[t]{2}{*}{$\mathrm{t}$} & \multirow{2}{*}{ Sig. (2-tailed) } & \multirow{2}{*}{ Mean Difference } & \multicolumn{2}{|c|}{$\begin{array}{l}\text { 95\% Confidence Interval of the } \\
\text { Difference }\end{array}$} & \multirow[t]{2}{*}{ Significance? } \\
\hline & & & & Lower & Upper & \\
\hline Distortion and cracking of ground floor & -.519 & .604 & -.01935 & -.0928 & .0541 & Not significan \\
\hline Cracking in external wall & 12.718 & .000 & .80968 & .6844 & .9350 & Significant \\
\hline $\begin{array}{l}\text { Internal staining, mould growth and fungal decay on } \\
\text { external wall }\end{array}$ & 3.259 & .001 & .13871 & .0550 & .2225 & Significant \\
\hline Water staining, mould growth and decay on roof & -8.272 & .000 & -.24839 & -.3075 & -.1893 & Significant \\
\hline Deterioration of roof covering & -12.564 & .000 & -.31935 & -.3694 & -.2693 & Significant \\
\hline Deformation and displacement of roof & -11.879 & .000 & -.28710 & -.3347 & -.2395 & Significant \\
\hline Inadequate resistance to the passage of sound & 3.910 & .000 & .17419 & .0865 & .2618 & Significant \\
\hline Distortion and cracking of partition & 6.454 & .000 & .25484 & .1771 & .3325 & Significant \\
\hline Total failure of water supply system & 21.214 & .000 & .97742 & .8868 & 1.0681 & Significant \\
\hline Poor ventilation system & -1.330 & .184 & -.04839 & -.1200 & .0232 & Not significan \\
\hline Surcharge of drains and flooring & -8.738 & .000 & -.33871 & -.4150 & -.2624 & Significant \\
\hline Fracture and displacement of drains & -6.620 & .000 & -.19355 & -.2511 & -.1360 & Significant \\
\hline Uneven floor finishes & .817 & .414 & .03226 & -.0454 & .1099 & Not significan \\
\hline Uneven wall plaster & .314 & .754 & .01290 & -.0679 & .0937 & Not significan \\
\hline Broken floor tiles & -.073 & .942 & -.00323 & -.0898 & .0834 & Not significan \\
\hline Broken wall tiles & -1.921 & .056 & -.07742 & -.1567 & .0019 & Not significan \\
\hline Dampness to concrete wall & 8.775 & .000 & .44194 & .3428 & .5410 & Significant \\
\hline Faulty door knobs & 15.963 & .000 & .75161 & .6590 & .8443 & Significant \\
\hline Broken window knobs & 6.737 & .000 & .24516 & .1736 & .3168 & Significant \\
\hline Faulty sanitary installation & 3.342 & .001 & .12258 & .0504 & .1947 & Significant \\
\hline Exposed wires & -2.857 & .005 & -.11290 & -.1907 & -.0352 & Significant \\
\hline Faulty electrical fitting & 2.002 & .046 & .08065 & .0014 & .1599 & Significant \\
\hline Leakage of pipe & 21.287 & .000 & 1.09355 & .9925 & 1.1946 & Significant \\
\hline Dampness to floor & -2.184 & .030 & -.08387 & -.1594 & -.0083 & Significant \\
\hline Leakage of water tank & 2.579 & .010 & .11290 & .0268 & .1990 & Significant \\
\hline
\end{tabular}

\section{Accepted Manuscript Not Copyedited}


Table 8: Type of defects with it respective degree of frequency

\begin{tabular}{|c|c|c|}
\hline Type of defect & Mean & Degree of Frequency \\
\hline \multicolumn{3}{|l|}{ Foundation and floor structure } \\
\hline Distortion and cracking of ground floor & 1.48 & Never \\
\hline \multicolumn{3}{|l|}{ External wall } \\
\hline Cracking in external wall & 2.31 & Very frequent \\
\hline $\begin{array}{l}\text { Internal staining, mould growth and fungal decay on } \\
\text { external wall }\end{array}$ & 1.64 & Rarely \\
\hline \multicolumn{3}{|l|}{ Roof } \\
\hline Water staining, mould growth and decay on roof & 1.25 & Never \\
\hline Deterioration of roof covering & 1.18 & Never \\
\hline Deformation and displacement of roof & 1.21 & Never \\
\hline \multicolumn{3}{|l|}{ Internal wall and floor } \\
\hline Inadequate resistance to the passage of sound & 1.67 & Rarely \\
\hline Distortion and cracking of partition & 1.75 & Rarely \\
\hline \multicolumn{3}{|l|}{ Above ground service } \\
\hline Total failure of water supply system & 2.48 & Very frequent \\
\hline Poor ventilation system & 1.45 & Never \\
\hline \multicolumn{3}{|l|}{ Below ground drainage and external wall } \\
\hline Surcharge of drains and flooring & 1.16 & Never \\
\hline Fracture and displacement of drains & 1.30 & Never \\
\hline \multicolumn{3}{|l|}{ Wall and floor finishes } \\
\hline Uneven floor finishes & 1.53 & Rarely \\
\hline Uneven wall plaster & 1.51 & Never \\
\hline Broken floor tiles & 1.50 & Never \\
\hline Broken wall tiles & 1.42 & Never \\
\hline \multicolumn{3}{|l|}{ Damp proof course } \\
\hline Dampness to concrete wall & 1.94 & Frequent \\
\hline Dampness to floor & 1.42 & Never \\
\hline \multicolumn{3}{|l|}{ Door and window fixings } \\
\hline Faulty door knobs & 2.25 & Very frequent \\
\hline Broken window knobs & 1.75 & Rarely \\
\hline \multicolumn{3}{|l|}{ Sanitary installation } \\
\hline Faulty sanitary installation & 1.62 & Rarely \\
\hline \multicolumn{3}{|l|}{ Electrical installation } \\
\hline Exposed wires & 1.39 & Never \\
\hline Faulty electrical fitting & 1.58 & Rarely \\
\hline \multicolumn{3}{|l|}{ Piping work } \\
\hline Leakage of pipe & 2.59 & Very frequent \\
\hline Leakage of water tank & 1.61 & Rarely \\
\hline
\end{tabular}

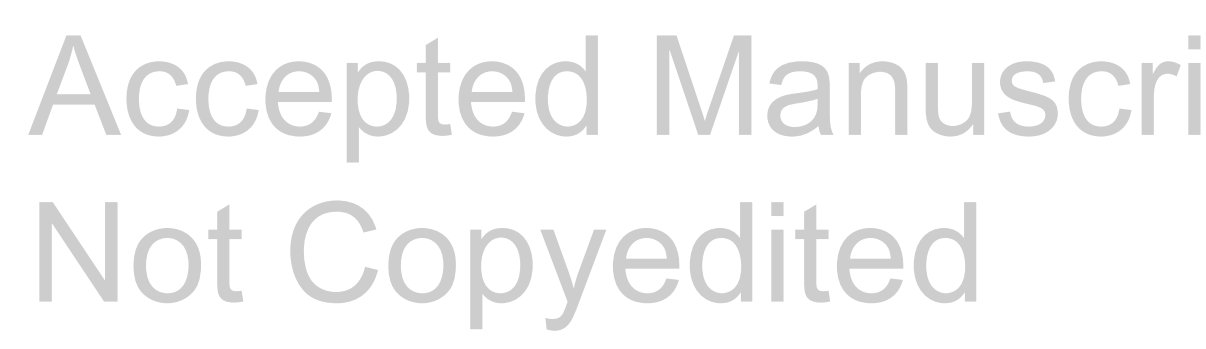


Journal of Performance of Constructed Facilities. Submitted September 13, 2012; accepted October 23, 2012; posted ahead of print October 25, 2012. doi:10.1061/(ASCE)CF.1943-5509.0000413

Table 9: Number and percentage of defects for each degree of frequency

\begin{tabular}{|l|c|c|}
\hline Degree of frequency & Number of defect & Percentage (\%) \\
\hline Never & 12 & 48.00 \\
\hline Rarely & 8 & 32.00 \\
\hline Frequent & 1 & 4.00 \\
\hline Very frequent & 4 & 16.00 \\
\hline
\end{tabular}

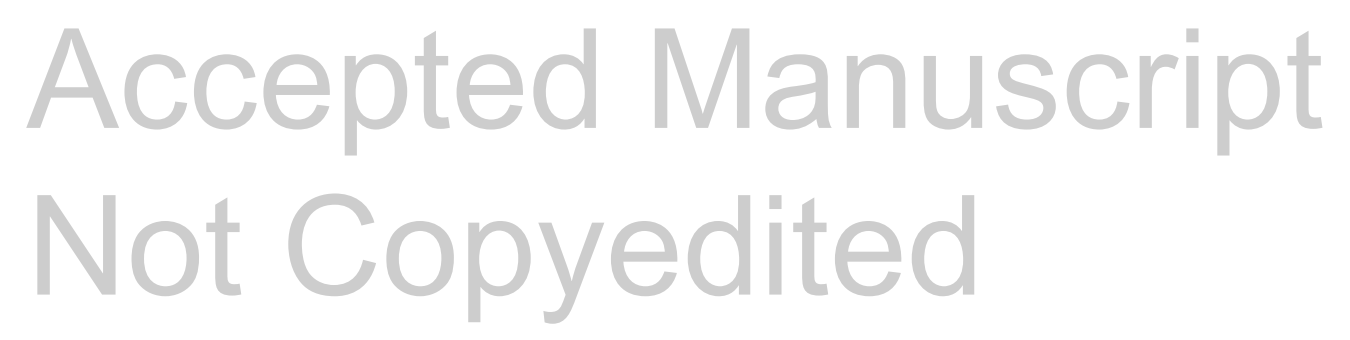

Copyright 2012 by the American Society of Civil Engineers

J. Perform. Constr. Facil. 
Table 10: Correlations matrix of the variables

\begin{tabular}{|c|c|c|c|c|c|c|}
\hline & & $\begin{array}{l}\text { cracking in } \\
\text { external wall }\end{array}$ & $\begin{array}{c}\text { total failure of } \\
\text { water supply } \\
\text { system }\end{array}$ & $\begin{array}{l}\text { dampness to } \\
\text { concrete wall }\end{array}$ & faulty door knobs & leakage of pipe \\
\hline \multirow[t]{3}{*}{ cracking in external wall } & Pearson Correlation & 1 & \multirow{3}{*}{ Weak } & \multirow{3}{*}{ Strong } & \multirow{3}{*}{ No Relationship } & \multirow{3}{*}{ Moderate } \\
\hline & Sig. (2-tailed) & & & & & \\
\hline & $\mathrm{N}$ & 310 & & & & \\
\hline \multirow{3}{*}{$\begin{array}{l}\text { total failure of water supply } \\
\text { system }\end{array}$} & Pearson Correlation & $.243^{* *}$ & 1 & \multirow{3}{*}{ Weak } & \multirow{3}{*}{ Weak } & \multirow{3}{*}{ Weak } \\
\hline & Sig. (2-tailed) & .000 & & & & \\
\hline & $\mathrm{N}$ & 310 & 310 & & & \\
\hline \multirow[t]{3}{*}{ dampness to concrete wall } & Pearson Correlation & $.575^{* *}$ & $.142^{*}$ & 1 & \multirow{3}{*}{ No Relationship } & \multirow{3}{*}{ Strong } \\
\hline & Sig. (2-tailed) & .000 & .012 & & & \\
\hline & $\mathrm{N}$ & 310 & 310 & 310 & & \\
\hline \multirow[t]{3}{*}{ faulty door knobs } & Pearson Correlation & -.011 & $.158^{* *}$ & .033 & 1 & \multirow{3}{*}{ No Relationship } \\
\hline & Sig. (2-tailed) & .847 & .005 & .561 & & \\
\hline & $\mathrm{N}$ & 310 & 310 & 310 & 310 & \\
\hline \multirow[t]{3}{*}{ leakage of pipe } & Pearson Correlation & $.412^{* *}$ & $.182^{* *}$ & $.535^{* *}$ & .016 & 1 \\
\hline & Sig. (2-tailed) & .000 & .001 & .000 & .779 & \\
\hline & $\mathrm{N}$ & 310 & 310 & 310 & 310 & 310 \\
\hline
\end{tabular}

**. Correlation is significant at the 0.01 level (2-tailed).

*. Correlation is significant at the 0.05 level (2-tailed).

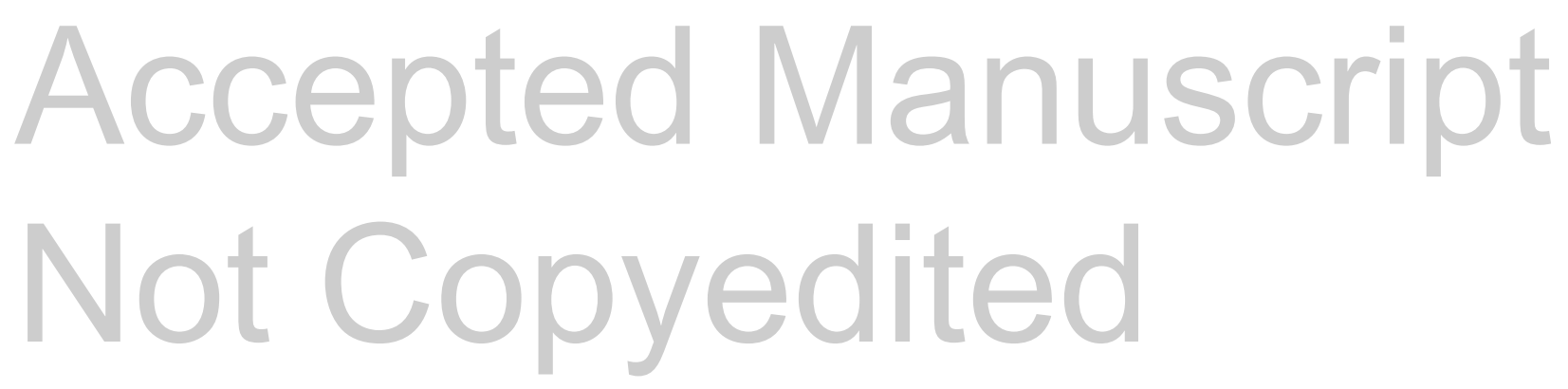


Journal of Performance of Constructed Facilities. Submitted September 13, 2012; accepted October 23, 2012; posted ahead of print October 25, 2012. doi:10.1061/(ASCE)CF.1943-5509.0000413

Table 11: Partial correlation matrix of the variables, controlling for total failure of cracking in external wall

\begin{tabular}{|c|c|c|c|c|c|c|}
\hline \multicolumn{3}{|c|}{ Control Variables } & $\begin{array}{l}\text { cracking in external } \\
\text { wall }\end{array}$ & $\begin{array}{l}\text { dampness to } \\
\text { concrete wall }\end{array}$ & faulty door knobs & leakage of pipe \\
\hline \multirow[t]{4}{*}{ total failure of water supply system } & cracking in external wall & $\begin{array}{c}\text { Correlation } \\
\text { Significance (2-tailed) } \\
\text { df }\end{array}$ & $\begin{array}{c}1.000 \\
. \\
0\end{array}$ & $\begin{array}{l}.563 \\
.000 \\
307\end{array}$ & $\begin{array}{l}-.051 \\
\\
.368 \\
307\end{array}$ & $\begin{array}{l}.386 \\
.000 \\
307\end{array}$ \\
\hline & dampness to concrete wall & $\begin{array}{c}\text { Correlation } \\
\text { Significance (2-tailed) } \\
\text { df }\end{array}$ & $\begin{array}{l}.563 \\
.000 \\
307\end{array}$ & $\begin{array}{c}1.000 \\
. \\
0\end{array}$ & $\begin{array}{l}.011 \\
.848 \\
307\end{array}$ & $\begin{array}{l}.524 \\
.000 \\
307\end{array}$ \\
\hline & faulty door knobs & $\begin{array}{c}\text { Correlation } \\
\text { Significance (2-tailed) } \\
\text { df }\end{array}$ & $\begin{array}{l}-.051 \\
.368 \\
307 \\
\end{array}$ & $\begin{array}{l}.011 \\
.848 \\
307\end{array}$ & $\begin{array}{c}1.000 \\
. \\
0\end{array}$ & $\begin{array}{l}-.013 \\
.820 \\
307 \\
\end{array}$ \\
\hline & leakage of pipe & $\begin{array}{c}\text { Correlation } \\
\text { Significance (2-tailed) } \\
\text { df }\end{array}$ & $\begin{array}{l}.386 \\
.000 \\
307\end{array}$ & $\begin{array}{l}.524 \\
.000 \\
307\end{array}$ & $\begin{array}{l}-.013 \\
.820 \\
307\end{array}$ & $\begin{array}{c}1.000 \\
. \\
0\end{array}$ \\
\hline
\end{tabular}

\section{Accepted Manuscript Not Copyedited}


Journal of Performance of Constructed Facilities. Submitted September 13, 2012; accepted October 23, 2012;

posted ahead of print October 25, 2012. doi:10.1061/(ASCE)CF.1943-5509.0000413

Table 12: Partial correlation matrix of the variables, controlling for total failure of water supply system

\begin{tabular}{|c|c|c|c|c|c|c|}
\hline \multicolumn{3}{|c|}{ Control Variables } & $\begin{array}{l}\text { total failure of water } \\
\text { supply system }\end{array}$ & $\begin{array}{l}\text { dampness to } \\
\text { concrete wall }\end{array}$ & faulty door knobs & leakage of pipe \\
\hline \multirow[t]{4}{*}{ cracking in external wall } & total failure of water supply system & $\begin{array}{c}\text { Correlation } \\
\text { Significance (2-tailed) } \\
\text { df }\end{array}$ & $\begin{array}{c}1.000 \\
. \\
0\end{array}$ & $\begin{array}{l}.003 \\
.953 \\
307\end{array}$ & $\begin{array}{l}.165 \\
.004 \\
307\end{array}$ & $\begin{array}{l}.092 \\
.105 \\
307\end{array}$ \\
\hline & dampness to concrete wall & $\begin{array}{c}\text { Correlation } \\
\text { Significance (2-tailed) } \\
\text { df }\end{array}$ & $\begin{array}{l}.003 \\
.953 \\
307\end{array}$ & $\begin{array}{c}1.000 \\
0 \\
0\end{array}$ & $\begin{array}{l}.048 \\
.398 \\
307\end{array}$ & $\begin{array}{l}.401 \\
.000 \\
307\end{array}$ \\
\hline & faulty door knobs & $\begin{array}{c}\text { Correlation } \\
\text { Significance (2-tailed) } \\
\text { df }\end{array}$ & $\begin{array}{l}.165 \\
.004 \\
307\end{array}$ & $\begin{array}{l}.048 \\
.398 \\
307\end{array}$ & $\begin{array}{c}1.000 \\
. \\
0\end{array}$ & $\begin{array}{l}.023 \\
.694 \\
307\end{array}$ \\
\hline & leakage of pipe & $\begin{array}{c}\text { Correlation } \\
\text { Significance (2-tailed) } \\
\text { df }\end{array}$ & $\begin{array}{l}.092 \\
.105 \\
307\end{array}$ & $\begin{array}{l}.401 \\
.000 \\
307\end{array}$ & $\begin{array}{l}.023 \\
.694 \\
307\end{array}$ & $\begin{array}{c}1.000 \\
0 \\
0\end{array}$ \\
\hline
\end{tabular}

\section{Accepted Manuscript Not Copyedited}

Copyright 2012 by the American Society of Civil Engineers

J. Perform. Constr. Facil. 
Journal of Performance of Constructed Facilities. Submitted September 13, 2012; accepted October 23, 2012; posted ahead of print October 25, 2012. doi:10.1061/(ASCE)CF.1943-5509.0000413

Table 13: Partial correlation matrix of the variables, controlling for dampness to concrete wall

\begin{tabular}{|c|c|c|c|c|c|c|}
\hline \multicolumn{3}{|c|}{ Control Variables } & $\begin{array}{l}\text { cracking in external } \\
\text { wall }\end{array}$ & $\begin{array}{l}\text { total failure of water } \\
\text { supply system }\end{array}$ & faulty door knobs & leakage of pipe \\
\hline \multirow[t]{4}{*}{ dampness to concrete wall } & cracking in external wall & $\begin{array}{c}\text { Correlation } \\
\text { Significance (2-tailed) } \\
\text { df }\end{array}$ & $\begin{array}{c}1.000 \\
. \\
0\end{array}$ & $\begin{array}{l}.199 \\
.000 \\
307\end{array}$ & $\begin{array}{l}-.037 \\
.520 \\
307\end{array}$ & $\begin{array}{l}.151 \\
.008 \\
307\end{array}$ \\
\hline & total failure of water supply system & $\begin{array}{c}\text { Correlation } \\
\text { Significance (2-tailed) } \\
\text { df }\end{array}$ & $\begin{array}{l}.199 \\
.000 \\
307\end{array}$ & $\begin{array}{c}1.000 \\
\cdot \\
0\end{array}$ & $\begin{array}{l}.155 \\
.006 \\
307\end{array}$ & $\begin{array}{l}.126 \\
.027 \\
307\end{array}$ \\
\hline & faulty door knobs & $\begin{array}{c}\text { Correlation } \\
\text { Significance (2-tailed) } \\
\text { df } \\
\end{array}$ & $\begin{array}{l}-.037 \\
.520 \\
307 \\
\end{array}$ & $\begin{array}{l}.155 \\
.006 \\
307 \\
\end{array}$ & $\begin{array}{c}1.000 \\
. \\
0\end{array}$ & $\begin{array}{l}-.002 \\
.971 \\
307 \\
\end{array}$ \\
\hline & leakage of pipe & $\begin{array}{c}\text { Correlation } \\
\text { Significance (2-tailed) } \\
\text { df }\end{array}$ & $\begin{array}{l}.151 \\
.008 \\
307\end{array}$ & $\begin{array}{l}.126 \\
.027 \\
307\end{array}$ & $\begin{array}{l}-.002 \\
.971 \\
307\end{array}$ & $\begin{array}{c}1.000 \\
\cdot \\
0\end{array}$ \\
\hline
\end{tabular}

\section{Accepted Manuscript Not Copyedited}


Journal of Performance of Constructed Facilities. Submitted September 13, 2012; accepted October 23, 2012; posted ahead of print October 25, 2012. doi:10.1061/(ASCE)CF.1943-5509.0000413

Table 14: Partial correlation matrix of the variables, controlling for faulty door knobs

\begin{tabular}{|c|c|c|c|c|c|c|}
\hline \multicolumn{3}{|c|}{ Control Variables } & $\begin{array}{c}\begin{array}{c}\text { cracking in } \\
\text { external wall }\end{array} \\
1.000\end{array}$ & $\begin{array}{c}\begin{array}{c}\text { total failure of water } \\
\text { supply system }\end{array} \\
.247\end{array}$ & $\begin{array}{c}\begin{array}{c}\text { dampness to } \\
\text { concrete wall }\end{array} \\
.576\end{array}$ & $\frac{\text { leakage of pipe }}{.412}$ \\
\hline faulty door knobs & cracking in external wall & $\begin{array}{c}\text { Correlation } \\
\text { Significance (2-tailed) } \\
\text { df }\end{array}$ & $\begin{array}{c}1.000 \\
\\
. \\
0\end{array}$ & $\begin{array}{l}.247 \\
.000 \\
307\end{array}$ & $\begin{array}{l}.576 \\
.000 \\
307\end{array}$ & $\begin{array}{l}.412 \\
.000 \\
307\end{array}$ \\
\hline & total failure of water supply system & $\begin{array}{c}\text { Correlation } \\
\text { Significance (2-tailed) } \\
\text { df }\end{array}$ & $\begin{array}{l}.247 \\
.000 \\
307 \\
\end{array}$ & $\begin{array}{c}1.000 \\
. \\
0 \\
\end{array}$ & $\begin{array}{l}.139 \\
.015 \\
307 \\
\end{array}$ & $\begin{array}{l}.181 \\
.001 \\
307 \\
\end{array}$ \\
\hline & dampness to concrete wall & $\begin{array}{c}\text { Correlation } \\
\text { Significance (2-tailed) } \\
\text { df } \\
\end{array}$ & $\begin{array}{l}.576 \\
.000 \\
307 \\
\end{array}$ & $\begin{array}{l}.139 \\
.015 \\
307 \\
\end{array}$ & $\begin{array}{c}1.000 \\
. \\
0\end{array}$ & $\begin{array}{l}.535 \\
.000 \\
307 \\
\end{array}$ \\
\hline & leakage of pipe & $\begin{array}{c}\text { Correlation } \\
\text { Significance (2-tailed) } \\
\text { df }\end{array}$ & $\begin{array}{l}.412 \\
.000 \\
307\end{array}$ & $\begin{array}{l}.181 \\
.001 \\
307\end{array}$ & $\begin{array}{l}.535 \\
.000 \\
307\end{array}$ & $\begin{array}{c}1.000 \\
\cdot \\
0\end{array}$ \\
\hline
\end{tabular}

\section{Accepted Manuscript Not Copyedited}

Copyright 2012 by the American Society of Civil Engineers

J. Perform. Constr. Facil. 
Journal of Performance of Constructed Facilities. Submitted September 13, 2012; accepted October 23, 2012; posted ahead of print October 25, 2012. doi:10.1061/(ASCE)CF.1943-5509.0000413

Table 15: Partial correlation matrix of the variables, controlling for leakage of pipe

\begin{tabular}{|c|c|c|c|c|c|c|}
\hline \multicolumn{3}{|c|}{ Control Variables } & $\frac{\begin{array}{c}\text { cracking in } \\
\text { external wall }\end{array}}{1.000}$ & $\begin{array}{c}\begin{array}{c}\text { total failure of water } \\
\text { supply system }\end{array} \\
.187\end{array}$ & $\frac{\begin{array}{c}\text { dampness to } \\
\text { concrete wall }\end{array}}{.460}$ & $\begin{array}{c}\text { faulty door knobs } \\
-.019\end{array}$ \\
\hline leakage of pipe & cracking in external wall & $\begin{array}{c}\text { Correlation } \\
\text { Significance (2-tailed) } \\
\text { df }\end{array}$ & $\begin{array}{c}1.000 \\
. \\
0\end{array}$ & $\begin{array}{l}.187 \\
.001 \\
307\end{array}$ & $\begin{array}{l}.460 \\
\\
.000 \\
307\end{array}$ & $\begin{array}{r}-.019 \\
\\
.736 \\
307\end{array}$ \\
\hline & total failure of water supply system & $\begin{array}{c}\text { Correlation } \\
\text { Significance (2-tailed) } \\
\text { df } \\
\end{array}$ & $\begin{array}{l}.187 \\
.001 \\
307 \\
\end{array}$ & $\begin{array}{c}1.000 \\
\cdot \\
0\end{array}$ & $\begin{array}{l}.054 \\
.343 \\
307 \\
\end{array}$ & $\begin{array}{l}.157 \\
.006 \\
307 \\
\end{array}$ \\
\hline & dampness to concrete wall & $\begin{array}{c}\text { Correlation } \\
\text { Significance (2-tailed) } \\
\text { df }\end{array}$ & $\begin{array}{l}.460 \\
.000 \\
307\end{array}$ & $\begin{array}{l}.054 \\
.343 \\
307\end{array}$ & $\begin{array}{c}1.000 \\
. \\
0\end{array}$ & $\begin{array}{l}.029 \\
.610 \\
307\end{array}$ \\
\hline & faulty door knobs & $\begin{array}{c}\text { Correlation } \\
\text { Significance (2-tailed) } \\
\text { df }\end{array}$ & $\begin{array}{l}-.019 \\
.736 \\
307\end{array}$ & $\begin{array}{l}.157 \\
.006 \\
307\end{array}$ & $\begin{array}{l}.029 \\
.610 \\
307\end{array}$ & $\begin{array}{l}1.000 \\
. \\
0\end{array}$ \\
\hline
\end{tabular}

\section{Accepted Manuscript Not Copyedited}

Copyright 2012 by the American Society of Civil Engineers

J. Perform Constr. Facil. 


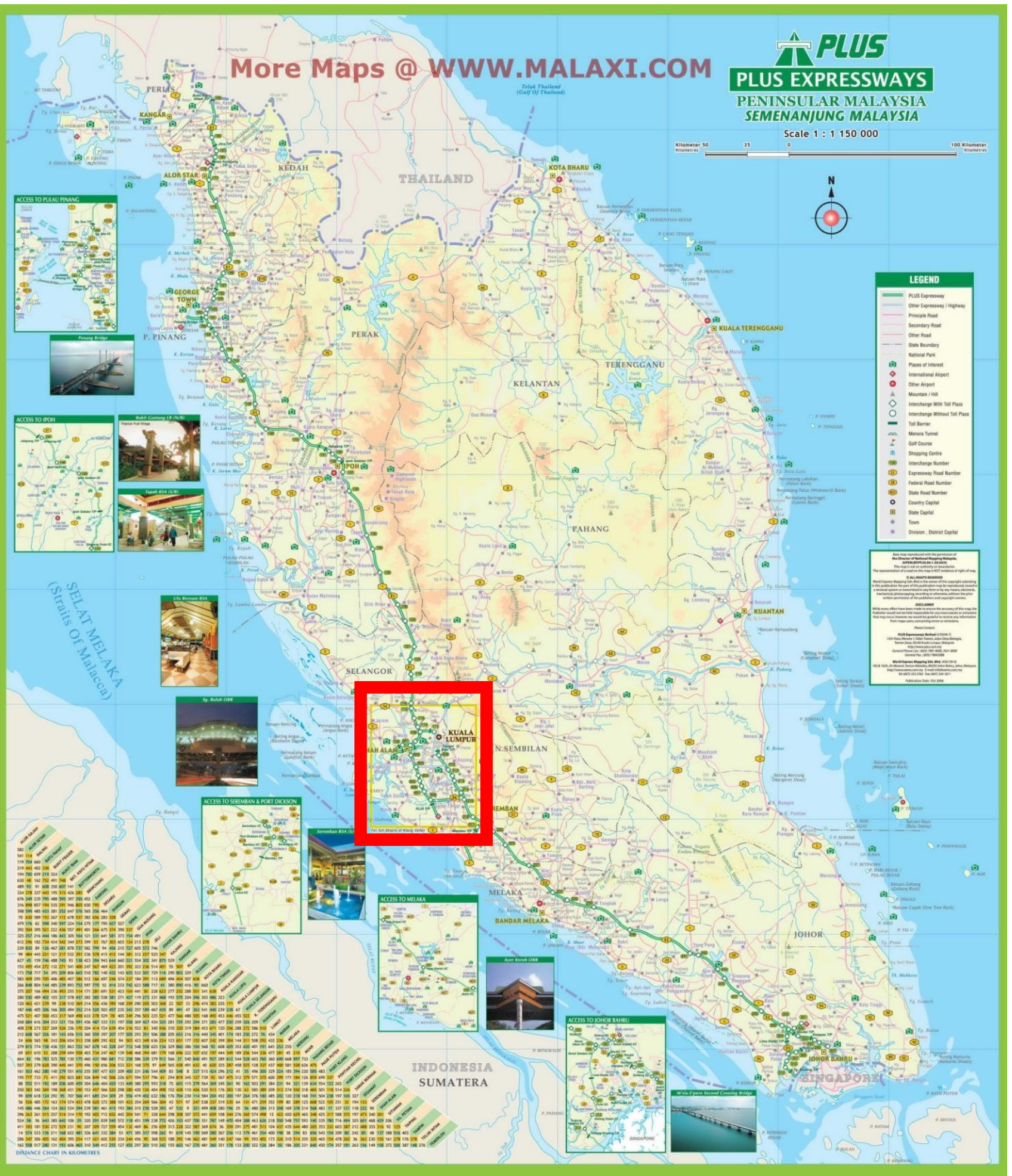

Figure 1: Location of Klang Valley, Malaysia shown in read pane

(http://www.malaxi.com/highway_express/images/plus_expressways_map.jpg)

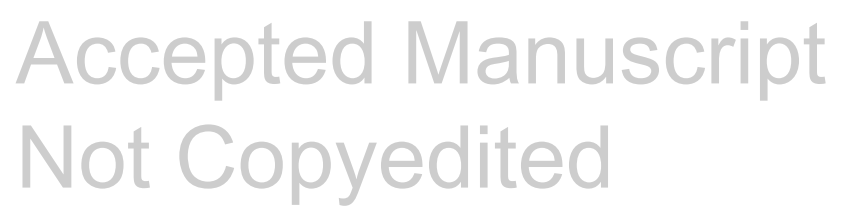

